\title{
Antimicrobial, antioxidant, toxicity and phytochemical assessment of extracts from Acmella uliginosa, a leafy-vegetable consumed in Bénin, West Africa
}

\author{
Latifou Lagnika ${ }^{1 *}$, Abdou Madjid O. Amoussa ${ }^{1}$, Rafatou A. A. Adjileye ${ }^{1}$, Anatole Laleye ${ }^{2}$ and Ambaliou Sanni ${ }^{1}$
}

\begin{abstract}
Background: Acmella uliginosa (Asteraceae) is a flowering plant whose leaves are consumed as a vegetable in Benin. They are also traditionally used as an antibiotic in the treatment of infectious diseases. To evaluate the therapeutic potential and toxicity effect of this leafy-vegetable, the antibacterial, antifungal, antioxidant activities and, toxicity and phytochemical constituents were investigated.
\end{abstract}

Methods: Dichloromethane, methanol and aqueous extracts of Acmella uliginosa were evaluated for their antimicrobial activity against six bacterial and six fungi strains. Antibacterial and antifungal activities were investigated by microdilution method and agar diffusion method respectively. Antioxidant activity was assessed using the 2,2-diphenyl-1-picryl-hydrazyl assay and phytochemical screening was carried out using standard procedures. Finally, oral acute toxicity at a dose of $2000 \mathrm{mg} / \mathrm{kg}$ was done according to the Organization for Economic Co-operation and Development guideline $\mathrm{n}^{\circ} 423$.

Results: The antibacterial activity was broad spectrum, inhibiting both Gram-positive and Gram-negative bacteria. The minimum inhibitory concentration ranged from 0.625 to $5 \mathrm{mg} / \mathrm{ml}$. The antifungal evaluation show that all the extracts inhibited mycelial growth and sporulation of fungi with percentages of inhibition ranging from 9.39 to $75.67 \%$ and 22.04 to $99.77 \%$, respectively. In DPPH radical scavenging assay, the effect on reducing free radicals increased in a dose dependent manner. The percentage of inhibition of DPPH ranged from 0.94 to $73.07 \%$. Phytochemical screening revealed the presence of coumarin, flavonoid, naphtoquinone, anthracene derivative, saponin, lignan, triterpene and tannin. The dichloromethane and methanol extracts showed the best biological activities; they were also shown as the best extraction solvents of phytochemicals. In the acute toxicity evaluation, all animals were physically active and no deaths of rats were observed during the test. However, the aqueous extract promoted biochemical, hematological and histopathological alterations of treated rats at $2000 \mathrm{mg} / \mathrm{kg}$ body weight.

Conclusion: A. uliginosa extracts contains antimicrobial, antioxidant agents and was not lethal for rats when ingested. However, according to the results obtained for biochemical, hematological, and histopathological analysis, caution is required regarding its consumption.

Keywords: Acmella uliginosa, Antifungal, Antibacterial, Antioxidant, Toxicity, Phytochemical

\footnotetext{
* Correspondence: llagnika@gmail.com

${ }^{1}$ Unité de Biochimie et Biologie Moléculaire, Equipe de Biochimie et Substances Naturelles Bioactives, Faculté des Sciences et Techniques, Université d'Abomey-Calavi, Cotonou 04 BP 0320, Bénin

Full list of author information is available at the end of the article
} 


\section{Background}

The nutrition and health of the world population are the main upcoming challenges particularly in developing countries. In Sub Saharan Africa, there are more than 45,000 plant species of which about 1000 can be consumed as leafy vegetables which happen to be the mainstay of traditional African diets [1]. Leafy vegetables are plant species whose leaves are used as a vegetable in the sauce preparation. They play a very important role in our diet and are the most readily available sources of carbohydrates, fats, proteins, vitamins, minerals, essential amino acids [2, 3]. Many leafy vegetables are mainly consumed for their nutritional values since immemorial times without much consideration for their medicinal importance. Apart from their nutritional intake, they have the ability to synthesize several secondary metabolites of relatively complex structures possessing antioxidants [4]. These metabolites produce specific effects on the physiology of human being and other organisms. Recent reports indicate that there is an inverse relationship between the dietary intake of antioxidant rich foods and the incidence of human diseases [5]. The interest on these leafy vegetable has increased as a result of epidemiological studies linking eating habits and prevalence of certain diseases. Previous research indicated antimicrobial [6, 7], antidiabetic [8], anti-histaminic [9], anti-carcinogenic and hypolipidemic $[10,11]$ properties of leafy vegetables. Leafy vegetables are popular in Benin but there is no scientific data available on their medicinal properties and toxicity.

Acmella uliginosa (Sw.) Cass. (Asteracea) is a species of flowering plant which is indigenous and widely distributed in the tropics and sub-tropics especially in the West Indies, Venezuela, Brazil, Africa, Indonesia and Malaysia [12]. It is found in the North-west of Benin specifically in Atacora region [13]. Acmella uliginosa is commonly used by the Malay community in Malaysia to relieve pain often associated with mouth ulcers, toothache, sore throat, and stomach ache [14]. The methanolic flowers extract was reported to display potent antinociceptive property [15]. In Benin it is a traditional leafy vegetable which has been domesticated in rural areas and whose sauce is a good dewormer and antibiotic $[13,14]$. Aside these reports, and to the best of our knowledge, no other pharmacological effects of this plant related to its traditional use as antibiotic have been reported. Therefore, the objectives of the present study were (1) to evaluate the antimicrobial and antioxidant properties of the extracts of Acmella uliginosa leaves; (2) to determine the toxicity of aqueous extract of $A$. uliginosa using an acute oral toxicity test in animal models.

\section{Methods}

\section{Plant collection}

The leaves of $A$. uliginosa were collected in September 2012 from the airport garden of Cotonou, department of
Littoral, Southern Benin. Identification of the specie was carried out by botanists from the University of AbomeyCalavi and a voucher specimen (AA6624/HNB) was deposited at the National Herbarium of Bénin. After identification, the collected leaves were ground using an electric grinder (MARLEX Electroline Excella).

\section{Extracts preparation}

The leaves of A. uliginosa (620 g) were successively extracted by maceration with $1000 \mathrm{ml}$ of dichloromethane (DCM) and $750 \mathrm{ml}$ of methanol $(\mathrm{MeOH})$ for $72 \mathrm{~h}$ stirring while a second extraction (decoction) with $1000 \mathrm{ml}$ of sterile distilled water $\left(\mathrm{H}_{2} \mathrm{O}\right)$ was carried out with five hundred grams (500 g) of plant material. Each extraction was repeated three times. The filtrates of each extraction were desiccated under vacuum and the obtained extracts were stored at $4^{\circ} \mathrm{C}$ until biological assay.

\section{Phytochemical}

Phytochemical screening of the plant was carried out according to the standards methods for the detection of plant secondary metabolites [16, 17]. Alkaloids, flavonoids, steroids, coumarins, saponins, naphthoquinones, triterpenes, lignans, pigments, anthracene derivatives were investigated using TLC method [16] while tannins were characterized using iron-III-chloride reagent [17].

\section{Antibacterial activity \\ Bacterial strains}

Dichloromethane, methanol and aqueous extracts of $A$. uliginosa were individually tested against a panel of bacteria including four Gram-positive: Staphylococcus aureus (ATCC 6538), S. epidermidis (CIP8039), Enterococcus faecalis (ATCC 29212), Staphylococcus aureus Methicillin Resistant (SARM) and two Gram-negative: Escherichia coli (CIP 53126) and Pseudomonas aeruginosa (CIP82118) obtained from Laboratoire de Biophotonique et Pharmacologie, University of Strasbourg, France.

\section{Growth inhibition effect of extracts at $10 \mathrm{mg} / \mathrm{ml}$}

Sensivity of different bacterial strains to various extracts was determined using 96-well microplate. The aim of this method was to eliminate the extracts, which at $10 \mathrm{mg} / \mathrm{ml}$ do not inhibit the growth of bacteria [18]. The extracts were reconstituted to a concentration of $20 \mathrm{mg} / \mathrm{ml}$ in acetone/Muller Hinton broth culture. A volume of $100 \mu \mathrm{l}$ of each extract $(20 \mathrm{mg} / \mathrm{ml})$ was introduced in triplicate microplate already seeded with $100 \mu \mathrm{l}$ of the Muller Hinton broth culture inoculums $\left(10^{6} \mathrm{CFU} / \mathrm{ml}\right)$ of the tested bacteria. The microplate was incubated at $37^{\circ} \mathrm{C}$. After $18 \mathrm{~h}$ of incubation, $40 \mu \mathrm{l}$ of $0.2 \mathrm{mg} / \mathrm{ml}$ solution of $p$-iodonitrotetrazolium (Sigma Aldrich) were added to each well and microplate was incubated at $37{ }^{\circ} \mathrm{C}$. Finally, after $30 \mathrm{~min}$, the color 
change (extract color to red) of mix in each well was examined to select actives extracts. Active extract do not change color.

\section{Minimum inhibitory concentration and total activity}

The Minimum inhibitory concentrations (MIC) of selected extracts were determined by the method of broth microdilution using $p$-iodonitrotetrazolium (INT) as an indicator of bacterial viability [19]. Briefly, $100 \mu \mathrm{l}$ of Mueller Hinton broth (DIFCO) were added to each well of a 96-well microplate and $100 \mu \mathrm{l}$ of extracts $(20 \mathrm{mg} / \mathrm{ml})$ were added to the first well (A) of the plate. A two-fold dilution was carried to make 8 concentrations. Then, $100 \mu \mathrm{l}$ of bacterial broth at $10^{6} \mathrm{CFU} / \mathrm{ml}$ were finally added into all the wells. After $18 \mathrm{~h}$ incubation at $37^{\circ} \mathrm{C}, 40 \mu \mathrm{l}$ of $p$-iodonitrotétrazolium $(0.2 \%)$ were added to each well and the incubated was continued at $37{ }^{\circ} \mathrm{C}$. After $1 \mathrm{~h}$ incubation, the MIC values were recorded. Gentamicin was used as positive control. Each assay was run in triplicate. The total activity of each extract was calculated by dividing the MICs with the amount of extract obtained from $1 \mathrm{~g}$ of plant material [20]. This value indicates the volume in which the active extract obtained from $1 \mathrm{~g}$ of dry plant material can be diluted to always have inhibitory activity against organisms [21].

\section{Antifungal assay Test organisms}

Fungi strains used in this study included Aspergillus flavus CMBB75, A. parasiticus CMBB20, A. ochraceus CMBB91, A. nidulans CMBB90, $A$. clavatus NCPT24 and A. fumigatus CMBB89. They were obtained from the laboratory of biochemistry and molecular biology at the University of Abomey. These microorganisms are the most common fungal pathogens of vegetables, animals and humans. They play an important role in opportunistic infections in immunocompromised patients [22].

\section{Antifungal test}

The in vitro antifungal activity of extracts was evaluated on mycelia development and sporulation as described previously by Dohou et al. [23] with minor modifications. $10 \mathrm{ml}$ of the mixture of potato dextrose agar-extract at $1 \mathrm{mg} / \mathrm{ml}$ were poured into sterile petri dishes. Fungi suspension were prepared in tween (5\%) and 100 spores were dropping in the center of petri dishes. After 5 days incubation at $25{ }^{\circ} \mathrm{C}$, the diameter of mycelia was measured and the number of spores was counted microscopically using Malassez cell. Each test was performed in triplicate. Three petri dishes containing potato dextrose agar without extract were used as negative control and Fluconazol $(100 \mu \mathrm{g} / \mathrm{ml})$ was used as positive control. The percentage of inhibition (PI) of extracts was determined according to the formula below:

$$
\mathrm{PI}(\%)=\frac{\mathrm{A}_{\mathrm{v} \text { control }}-\mathrm{A}_{\mathrm{v} \text { tested extract }}}{\mathrm{A}_{\mathrm{v} \text { control }}} \times 100
$$

In which $\mathrm{A}_{\mathrm{v} \text { control }}=$ average diameter of the mycelia or estimated number of spores of control $(n=3), \mathrm{A}_{\mathrm{v}}$ tested extract average diameter of the mycelia or estimated number of spores of tested extracts $(n=3)$.

\section{DPPH radical-scavenging activity}

The ability of the extracts to scavenge the DPPH $(2,2-$ diphenyl-1-picrylhydrazyl) radical was evaluated. The antioxidant activity was determined according to the method previously described by Velazquez et al. [24]. The stock solution of the extracts was prepared at $1 \mathrm{mg} / \mathrm{ml}$. Then, a two-fold serial dilution was carried to make 8 concentrations $(1-0.007 \mathrm{mg} / \mathrm{ml})$. Briefly, $1.5 \mathrm{ml}$ of a freshly prepared methanolic solution of DPPH (2\%) was mixed with $0.75 \mathrm{ml}$ of extract solution. After $15 \mathrm{~min}$ incubation in the dark, at room temperature, the absorbance of the mixture was read at $517 \mathrm{~nm}$ using a spectrophotometer (Jenway, Genova). The blank consisting of a mixture of $1.5 \mathrm{ml}$ of methanol and $0.75 \mathrm{ml}$ of extract solution. Quercetin was used as positive control. All assays were performed in triplicate. The percentage of inhibition of DPPH radical was calculated according to the following formula:

$$
\% \text { inhibition }=\frac{A_{\text {blank }}-A_{\text {sample }}}{A_{\text {blank }}} \times 100
$$

$\mathrm{A}_{\text {blank }}=$ absorbance of blank, $\mathrm{A}_{\text {sample }}=$ absorbance of tested extract

\section{Oral acute toxicity \\ Experimental animals}

Six female wistar rats with body weight ranged from 180$200 \mathrm{~g}$ were obtained from the Laboratoire de Biologie Humaine, Faculty of Medicine, University of AbomeyCalavi. The used animals were nulliparous and nonpregnant. The rats were fed with standard laboratory diets, given water ad libitum and maintained under laboratory conditions $\left(22 \pm 3{ }^{\circ} \mathrm{C}\right)$, a relative humidity between $30-70 \%$ and a constant light-dark schedule (12 h light/dark cycle).

\section{Oral acute toxicity testing}

The toxicity of the aqueous extract of A. uliginosa was evaluated according to the Organization for Economic Cooperation and Development guidelines $n^{\circ} 423$ [25]. The protocol related to acute toxicity test was approved by the scientific committee of research protocols (VPMAS/PFCR2/UAC), University of Abomey-Calavi, Bénin. A total of six females rats were divided into two groups with three animals each and kept in different cages for easy observation during experiment. Distilled water $(10 \mathrm{ml} / \mathrm{kg}$ body 
weight) was given to control group (group I). The group II was given a single dose of the aqueous extract solution (2000 mg/kg body weight). Following administration of extract, rats were closely monitored for $30 \mathrm{~min}$ and 2, 4, 8 and $24 \mathrm{~h}$. Mortality, food and water consumption and general acute toxicity or clinical symptoms were recorded. Body weight was also recorded on days 1, 7 and 14 .

\section{Haematological and biochemical parameters}

At the end of the experiment, all the rats were anaesthetized using thiopental at $0.5 \mathrm{ml} / \mathrm{Kg}$ body weight. Animals were then sacrificed and the blood for biochemical and hematological analysis were collected through cardiac puncture into ethylenediaminetetraacetic acid (EDTA) tubes. Each blood sample was analyzed for haematological parameters such as hematocrit $(\mathrm{Ht})$, red blood cells (Rbc), hemoglobin concentration ( $\mathrm{Hc}$ ), mean corpuscular hemoglobin concentration (MCHC), mean corpuscular volume (MCV), mean corpuscular hemoglobin levels $(\mathrm{MCH})$, white blood cells (Wbc), basophils (B), lymphocytes (L), monocytes (M)using an automatic hematological analyzer (Sysmex, XP-300, Japan). Biochemical parameters such as Glucose (GLU), Creatinine (CREA), cholesterol (CHOL), alanine aminotransferase (ALT), aspartate transaminase (AST) were determined using an autoanalyzer (ErbaChem 7, Germany). The liver and kidneys of rats (group I and II) were collected, weighed immediately and transferred to a saline solution. These organs were fixed in $10 \%$ buffered formalin for histological examination. The samples were then treated with increasing concentrations of ethanol and infiltrated with paraffin. Then, the thin cuts were made and stained with hematoxylin and eosin stains.

\section{Statistical analysis}

The $t$-student test was used for statistical analysis of data on body weight, hematological and biochemical parameters. The difference was considered statistically significant when the $p$ value was 0.05 or less $(p<0.05)$. All data were expressed as mean $\pm \mathrm{SD}$. The graphical representation was performed using the Graph Pad Prism 5.0 software (Microsoft, USA).

\section{Results}

\section{Phytochemical results}

The phytochemical experiments on fresh leaves of $A$. uliginosa revealed the presence of coumarin, flavonoid, naphtoquinone, anthracene derivative, saponin, lignan, triterpene and tannin (Table 1). Dichloromethane extract showed the presence of flavonoid, naphtoquinone, anthracene derivative, lignin and triterpene followed by methanolic extract (Coumarin, flavonoid, naphtoquinone, lignan and triterpene). Aqueous extract revealed coumarin,
Table 1 Phytochemicals screening of extracts from Acmella uliginosa

\begin{tabular}{lllll}
\hline Phytochemicals & Reagents & $\mathrm{DCM}$ & $\mathrm{MeOH}$ & $\mathrm{H}_{2} \mathrm{O}$ \\
\hline Coumarin & $10 \% \mathrm{KOH}-\mathrm{EtOH}$ & - & + & + \\
Flavonoid & $\mathrm{NP} / \mathrm{PEG}$ & + & + & - \\
Naphtoquinone & $10 \% \mathrm{KOH}-\mathrm{MeOH}$ & + & + & - \\
Alkaloid & Dragendorff & - & - & - \\
Anthracene derivative & $5 \% \mathrm{KOH}-\mathrm{EtOH}$ & + & - & - \\
Saponin & Vanillin-sulphuric acid & - & - & + \\
Lignan & Vanillin-phosphoric acid & + & + & - \\
Triterpene & Anisaldehyde-sulphuric acid & + & + & - \\
Tannin & Vanillin-sulphuric acid & - & - & + \\
Pigment & Anisaldehyde-sulphuric acid & - & - & - \\
\hline
\end{tabular}

DCM dichloromethane extract, $\mathrm{MeOH}$ Methanol extract, $\mathrm{H}_{2} \mathrm{O}$ aqueous extract; (+) present, (-) absence

saponin and tannin. However, the extracts did not show the presence of alkaloid and pigment.

\section{Antibacterial activity Growth inhibition effect of extracts at $10 \mathrm{mg} / \mathrm{ml}$}

Table 2 shows the result of the antibacterial potency of extracts of $A$. uliginosa against selected bacteria. The results showed that the tested microorganisms were more sensitive to the dichloromethane and methanol extracts than the aqueous extract. The dichloromethane extract was the most active by inhibiting the growth of five bacteria strains out of six (5/6). All extracts inhibited the growth of $E$. faecalis. The methanolic extract remains moderately active by inhibiting the growth of $E$. faecalis (Gram-positive) and P. aeruginosa (Gram-negative). Unlike other tested bacteria, E. coli was resistant to all extracts.

\section{Minimum inhibitory concentrations (MIC) and total activity}

The Minimum inhibitory concentrations (MIC) and total activity of extracts are recorded in Table 3. Several authors have defined concentration ranges to classify the antimicrobial activity of plant extracts and fractions. The activity is high if the MIC is $\leq 0.1 \mathrm{mg} / \mathrm{ml}$, moderate if $0.1<\mathrm{MIC} \leq$ $0.625 \mathrm{mg} / \mathrm{ml}$ and weak if $\mathrm{MIC}>0.625 \mathrm{mg} / \mathrm{ml}[21,26]$. Based on these criteria, leaf extracts of A. uliginosa showed moderate to low antimicrobial activity with MICs values ranging from 0.625 to $5 \mathrm{mg} / \mathrm{ml}$ (Table 3). The dichloromethane extract had moderate activity against all Grampositive bacteria with a MIC value of $0.625 \mathrm{mg} / \mathrm{ml}$. A MIC of $1.25 \mathrm{mg} / \mathrm{ml}$ was obtained with the same extract against $P$. aeruginosa (Gram-negative). The methanolic extract had weak antibacterial activity against $E$. faecalis and $P$. aeruginosa with a MIC of $1.25 \mathrm{mg} / \mathrm{ml}$. The aqueous extract had also shown weak antibacterial activity against $E$. faecalis $(\mathrm{MIC}=5 \mathrm{mg} / \mathrm{ml})$. The MIC of gentamicin range from 
Table 2 Antibacterial activity of leaves extracts from Acmella uliginosa at $10 \mathrm{mg} / \mathrm{ml}$

\begin{tabular}{|c|c|c|c|c|c|c|}
\hline \multirow[b]{3}{*}{ Extracts } & \multicolumn{6}{|c|}{ Growth inhibition effect of extracts at $10 \mathrm{mg} / \mathrm{ml}$} \\
\hline & \multicolumn{4}{|l|}{ Gram (+) } & \multicolumn{2}{|c|}{ Gram (-) } \\
\hline & S.aureus & S.a.m.r & S. ep epidermidis & E. faecalis & E. coli & P. a \\
\hline Dichloromethane & + & + & + & + & - & + \\
\hline Methanol & - & - & - & + & - & + \\
\hline Aqueous & - & - & - & + & - & - \\
\hline
\end{tabular}

(+): actives; (-) : not actives; S.aureus : Staphylococcus aureus; S.a.m.r : Staphylococcus aureus meticillin resistant; S. epidermidis : Staphylococcus epidermidis; E. faecalis: Enterococcus faecalis; P. aeruginosa: Pseudomonas aeruginosa

These results indicated extracts which at $10 \mathrm{mg} / \mathrm{ml}$ inhibited (+) or do not inhibit (-) the growth of the microorganisms. Only active extracts at $10 \mathrm{mg} / \mathrm{ml}$ will be used for the determination of minimal inhibitory concentration (MIC)

0.025 to $0.125 \mathrm{mg} / \mathrm{ml}$. The activity of the extracts was still low compared to gentamicin.

The total activity was determined to quantify the antibacterial activity by dividing the mass of extract from $1 \mathrm{~g}$ of the plant material by the MIC value. The extracts with higher total activity values are considered the best. The methanol extract had the highest antibacterial activity with a total activity of $23.71 \mathrm{ml}$ against E. faecalis and $P$. aeruginosa.

\section{Antifungal assay}

Acmella uliginosa leaves extract showed interesting antifungal activity by inhibiting the sporulation and the mycelia growth of tested fungi (Figs. 1 and 2).

The percentage of inhibition (PI) of extracts on mycelial growth ranging from $9.39 \%$ to $75.67 \%$ (Fig. 1). Only the dichloromethane extract exhibited the strongest activity against $A$. parasiticus with a PI value of $75.67 \%$. This extract also showed moderate activity against $A$. clavatus $(\mathrm{PI}=58.05 \%)$ and $A$. nidulans ( $\mathrm{PI}=56.38 \%)$. The dichloromethane extract was more active against $A$. parasiticus $(75.77 \%)$ and A. clavatus (58.05\%) than Fluconazol against $A$. parasiticus $(70.27 \%)$ and $A$. clavatus $(39.28 \%)$. The other extracts are less active (9.39\% $\leq \mathrm{PI} \leq 40.54 \%)$.
The effect of the extracts at the same concentration is more marked on the inhibition of sporulation than the mycelial growth. Contrary to mycelial growth, the percentage of inhibition of extracts on sporulation of fungi ranged from 22.04 to $99.77 \%$ (Fig. 2). The higher activity was showed by dichloromethane extract against $A$. parasiticus with a PI value of $99.77 \%$ whereas the lowest inhibition was obtained with aqueous extract against $A$. flavus $(\mathrm{PI}=22.04 \%)$.

\section{Antioxidant activity}

Each extract was measured for their ability to scavenge DPPH free radicals and results showed on Fig. 3. The results were expressed as percentage of inhibition of DPPH radical in comparison to Quercetin. All extracts showed antioxidant dose dependent activity in a concentration range of $7-1000 \mu \mathrm{g} / \mathrm{ml}$ (Fig. 3). From 7 to $125 \mu \mathrm{g} / \mathrm{ml}$, the scavenging effects of the extracts decreases in the following order $\mathrm{DCM}>\mathrm{MeOH}>\mathrm{H}_{2} \mathrm{O}$. At these concentrations, the percentage of inhibition (PI) varied from 0.94 to $25.96 \%$ compared to the control (27.59 to $88.86 \%)$. At $250 \mathrm{mg} / \mathrm{ml}$ the PI of extracts is about $26 \%$ for the three extracts while that of quercetin is $88.86 \%$. The scavenging effects of extracts at 500 and $1000 \mu \mathrm{g} / \mathrm{ml}$, increased as follows: $\mathrm{DCM}<\mathrm{MeOH}<\mathrm{H}_{2} \mathrm{O}$, and were ranging from 32

Table 3 Minimum inhibitory concentration and total activity of selected leaves extracts from Acmella uliginosa against tested bacteria

\begin{tabular}{|c|c|c|c|c|c|}
\hline \multirow[b]{3}{*}{ Extracts } & \multicolumn{5}{|c|}{ Minimum inhibitory concentration (mg/ml) } \\
\hline & \multicolumn{4}{|l|}{ Gram (+) } & \multirow{2}{*}{$\frac{\text { Gram }(-)}{P . \text { aeruginosa }}$} \\
\hline & S. aureus & S.a.m.r & S. epidermidis & E. faecalis & \\
\hline Dichloromethanee & 0.625 & 0.625 & 0.625 & 0.625 & 1.25 \\
\hline Methanol & - & - & - & 1.25 & 1.25 \\
\hline Aqueous & - & - & - & 5 & - \\
\hline Gentamicin & 0.062 & 0.062 & 0.062 & 0.025 & 0.125 \\
\hline \multicolumn{6}{|l|}{ Total activity (ml/g) } \\
\hline Dichloromethanee & 4.61 & 4.61 & 2.30 & 4.61 & 2.30 \\
\hline Methanol & - & - & - & 23.71 & 23.71 \\
\hline Aqueous & - & - & - & 7.3 & - \\
\hline
\end{tabular}

S.aureus: Staphylococcus aureus; S.a.m.r: Staphylococcus aureus meticillin resistant; S. epidermidis: Staphylococcus epidermidis; E. faecalis: Enterococcus faecalis; P. aeruginosa: Pseudomonas aeruginosa; (-): not tested 


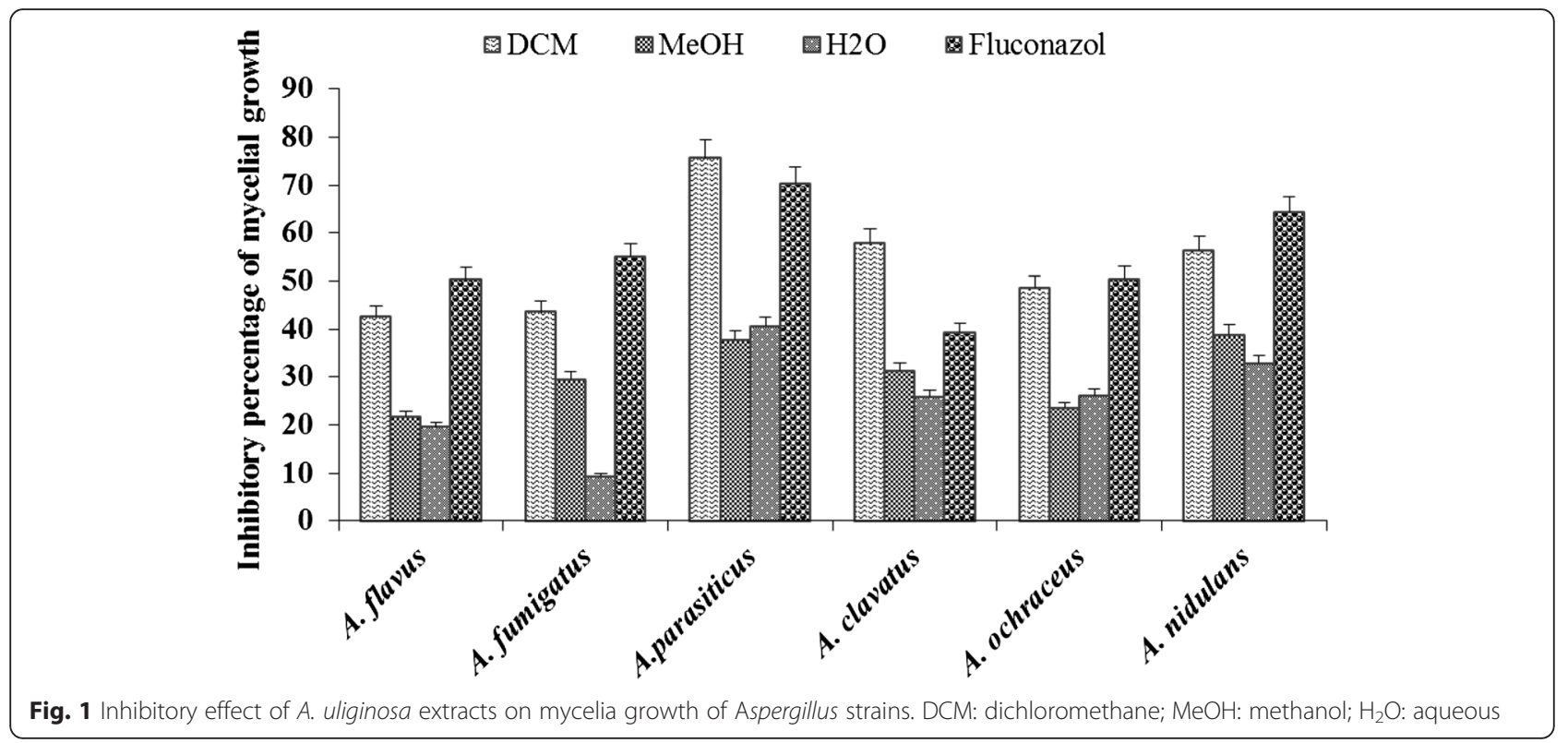

to $73.07 \%$. At the same concentration, the effect of the extracts remains weak compared to quercetin.

\section{Oral acute toxicity}

The oral acute toxicity evaluation showed that animals have tolerated the aqueous extract of A. uliginosa leaves at $2000 \mathrm{mg} / \mathrm{kg}$ body weight. The tested animals did not display any significant changes in behavioral pattern such as convulsion, diarrhea, salivation, breathing, and impairment in food intake, water consumption, postural abnormalities, hair loss, sleep, restlessness or in physical appearance such as eye color, mucous membrane when compared to the control at the end of 14 days of general observation. No mortality and no visible symptoms of acute toxicity were observed. These results indicated that the $\mathrm{LD}_{50}$ value of aqueous extract of A. uliginosa is greater than $2000 \mathrm{mg} / \mathrm{kg}$ body weight.

The body weight of treated rats gradually increased but was not significantly different compared to control (Fig. 4). Similarly, there was no significant difference between the relative liver weight of the test animals and the controls after 14 days of administration of the aqueous extract (Fig. 5). However, a significant increase $(P<0.05)$ was

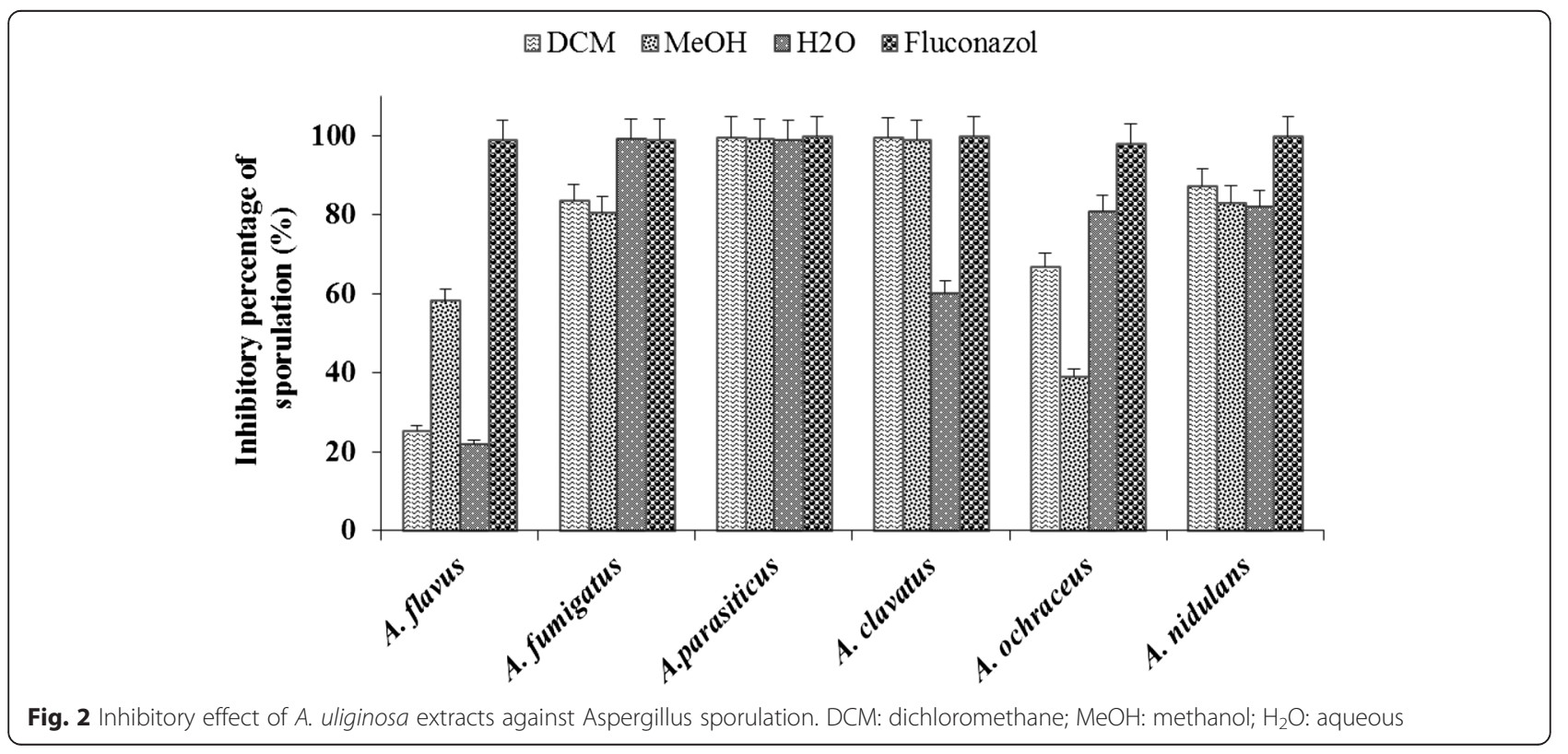




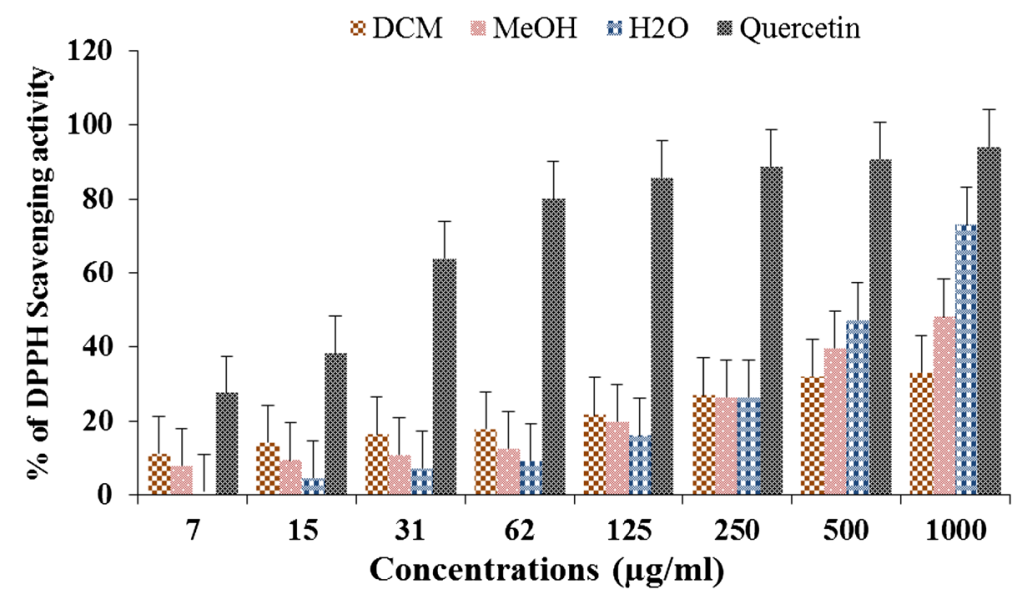

Fig. 3 DPPH free radical scavenging activity of $A$. uliginosa extracts. DCM: dichloromethane; $\mathrm{MeOH}$ : methanol; $\mathrm{H}_{2} \mathrm{O}$ : aqueous

observed in relative kidney weight of treated rats compared to control (Fig. 6).

The hematological parameters were examined in experimental animal after 14 days of administration of the aqueous leaf extracts of $A$. uliginosa. The results are shown in Table 4. Hematological parameters analyzed included the complete blood count of experimental and control group animals. Analysis of blood parameters in animal studies is relevant to evaluate the risk of alterations of the hematopoietic system in toxicity studies, for necessary application to humans [27]. After 14 days of administration of the aqueous extract of A. uliginosa, there was a significant increase $(p<0.05)$ of white blood cell count, mean corpuscular volume, mean corpuscular hemoglobin levels and neutrophil count in treated group compared to the control. In the same way, there was a significant decrease $(p<0.05)$ of hematocrit, red blood cell count, lymphocyte and monocyte number in treated groups.

Table 5 presents the effects of administration of aqueous extract of A. uliginosa on biochemical parameters in experimental rats after 14 days. A significant increase $(p<0.05)$ in creatinine value and a significant decrease $(p<0.05)$ in AST, ALT were observed in treated animals. The values of total cholesterol and glucose did not show any significant change.

Histological examination of visceral organs of treated animals showed a condensation of nucleus, a homogenization

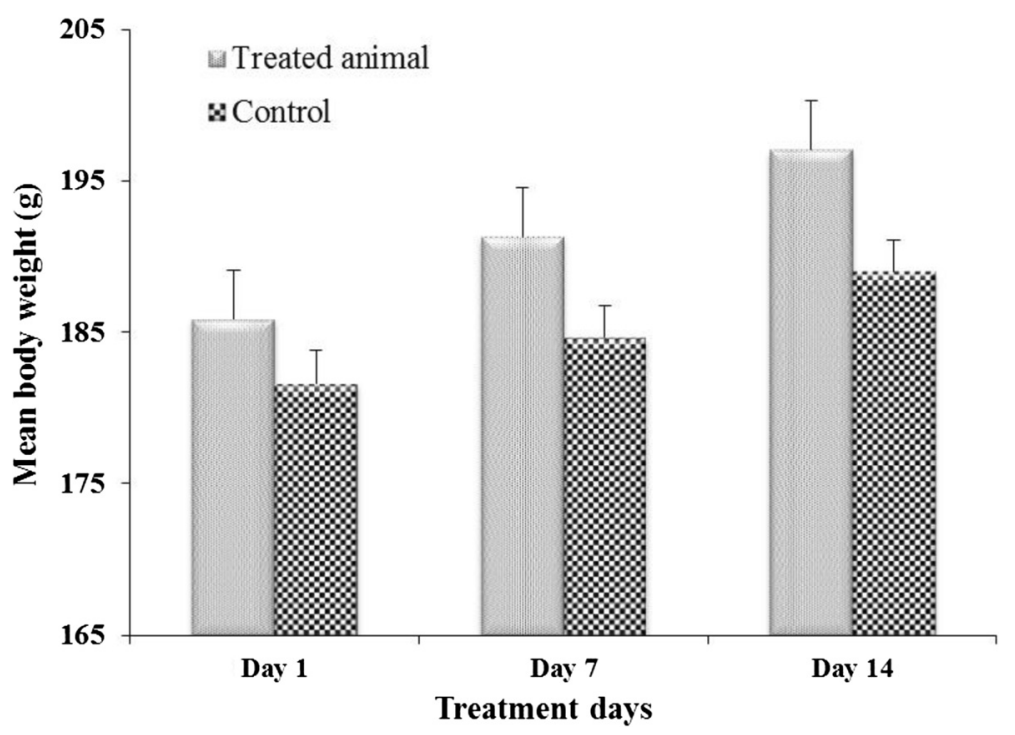

Fig. 4 Effect of aqueous extract on Mean body weight of rats for 14 days 


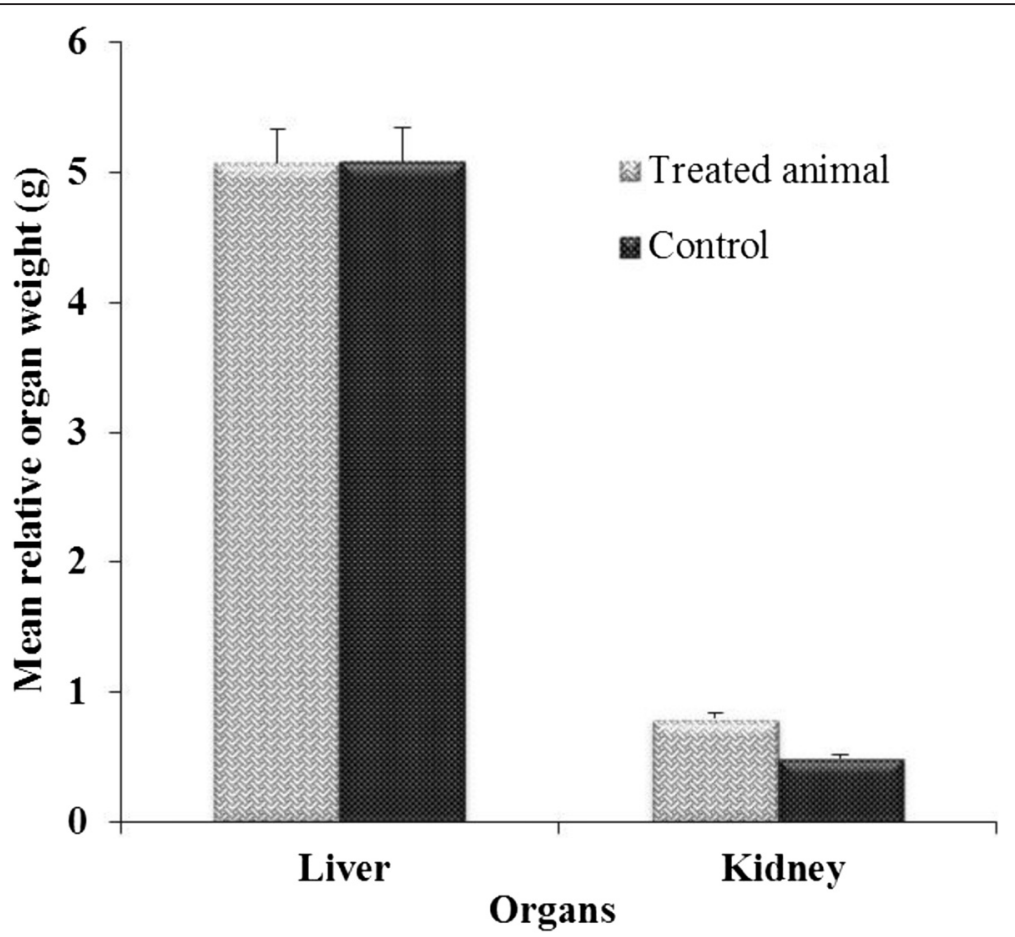

Fig. 5 Effect of aqueous extract of A. uliginosa $(2000 \mathrm{mg} / \mathrm{kg})$ on Mean relative weight of organs in rats for 14 days

and acidophilia of the cell cytoplasm as well as a reduction of capillary spaces in the liver. In the kidneys, histological examination revealed depletion of cortical glomeruli with hyalinization of the cortex and disappearance of urinary room, when compared to the control (Fig. 6).

\section{Discussion}

The therapeutic effects of plant materials generally result from the combination of secondary metabolites. These secondary metabolites are not only essential in the cell structure, but often are involved in the protection of
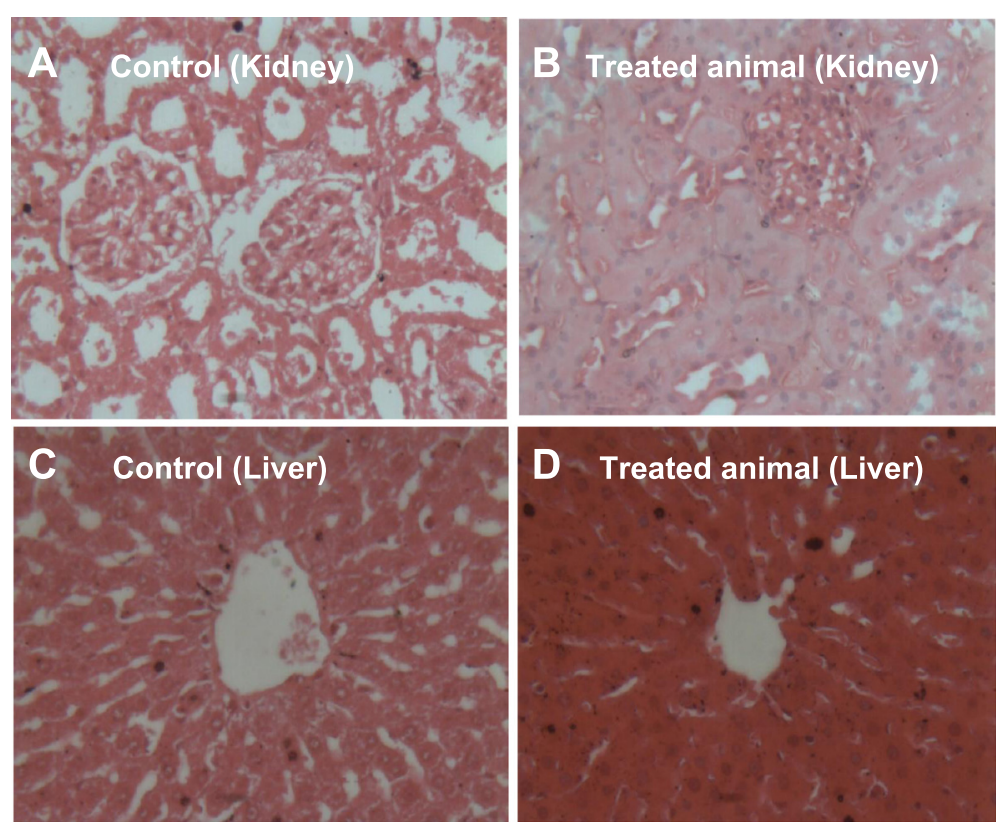

Fig. 6 Histological observations of kidney and liver tissues. a Kidney of control animal; b Kidney of treated animal; c Liver of control animal; d Liver of treated animal 
Table 4 Effect of aqueous extract of Acmella uliginosa on haematological parameters

\begin{tabular}{lll}
\hline Haematological Parameters & Experimental & Control \\
\hline $\mathrm{HC}(\mathrm{g} / \mathrm{dl})^{\mathrm{a}}$ & $13.27 \pm 0.93$ & $14.13 \pm 0.74$ \\
$\mathrm{Ht}(\%)^{\mathrm{b}}$ & $35.33 \pm 2.52$ & $43 \pm 4$ \\
$\mathrm{MCV}(\mathrm{fl} .)^{\mathrm{b}}$ & $88.33 \pm 1.53$ & $70.33 \pm 2.52$ \\
$\mathrm{MCH}(\mathrm{Pg})^{\mathrm{b}}$ & $33 \pm 1$ & $23 \pm 2$ \\
$\mathrm{MCHC}(\%)^{\mathrm{a}}$ & $37 \pm 00$ & $33.33 \pm 3.06$ \\
$\mathrm{Rbc}(\mathrm{T} / \mathrm{L})^{\mathrm{b}}$ & $3.99 \pm 0.32$ & $6.42 \pm 0.60$ \\
$\mathrm{Wbc}(\mathrm{G} / \mathrm{L})^{\mathrm{b}}$ & $6.43 \pm 1.50$ & $2.47 \pm 0.47$ \\
$\mathrm{NC}(\%)^{\mathrm{b}}$ & $40.67 \pm 8.14$ & $17.33 \pm 1.53$ \\
$\mathrm{~L}(\%)^{\mathrm{b}}$ & $59 \pm 7.94$ & $74.33 \pm 0.58$ \\
$\mathrm{M}(\%)^{\mathrm{b}}$ & $0.33 \pm 0.58$ & $6.33 \pm 2.08$
\end{tabular}

$\mathrm{Ht}$ hematocrit, Rbc red blood cells, Hc hemoglobin concentration, $\mathrm{MCHC}$ mean corpuscular hemoglobin concentration, MCV mean corpuscular volume, $\mathrm{MCH}$ mean corpuscular hemoglobin levels, Wbc white blood cells, Nc Neutrophil count, L lymphocytes, M monocytes. Values are mean \pm SEM ( $n=3$ per group), differences were considered significant when $p$-values were less than $0.05(p<0.05)$

${ }^{\mathbf{a}}$ : values non-significantly different; ${ }^{\mathbf{b}}$ : values significantly different

plants against biotic and abiotic stresses. Natural products, as pure compounds or standardized extracts, provide unlimited opportunities for the drug discovery because of the unmatched availability of chemical diversity inside the plants. Phytochemicals are bioactive compound present in leafy-vegetables which could be responsible for their bioactivity linked to the reduced risk of major chronic diseases. It has indeed been estimated that a healthy diet could prevent approximately $30 \%$ of all cancers [28]. The phytochemical screening showed that leaves of Acmella uliginosa contain coumarin, flavonoid, naphtoquinone, anthracene derivative, saponin, lignan, triterpene, and tannin. Bioactive compounds are normally accumulated as secondary metabolites in all plant cells but their concentration varies according to the plant parts, seasons, climates, extracting solvent in plant and particular growth phases [29]. Leaves are one of the highest sources of accumulation and are highly beneficial [30].

In this study, dichloromethane extract showed interesting antibacterial $(0.625-1.25 \mathrm{mg} / \mathrm{ml})$ and/or antifungal (PI up to $99.77 \%$ ) activity by inhibiting one or more

Table 5 Effects of aqueous extract of Acmella uliginosa on biochemical parameters

\begin{tabular}{lll}
\hline Biochemical parameters & Experimental & Control \\
\hline GLU $^{a}$ & $1.87 \pm 0.62$ & $1.34 \pm 0.08$ \\
CREA $^{\text {b }}$ & $48 \pm 7.94$ & $6.3 \pm 0.53$ \\
CHOL $^{a}$ & $0.68 \pm 0.10$ & $0.68 \pm 0.09$ \\
AST $^{b}$ & $152.67 \pm 23.29$ & $255.67 \pm 10.26$ \\
ALT $^{\text {b }}$ & $76 \pm 11.79$ & $111.33 \pm 44.29$
\end{tabular}

GLU Glucose, CREA Creatinine, CHOL cholesterol, ALT alanine aminotransferase, AST aspartate transaminase. Values are mean $\pm \operatorname{SEM}(n=3$ per group), differences were considered significant when $p$-values were less than $0.05(p<0.05)$

${ }^{\mathbf{a}}$ : values non-significantly different; ${ }^{\mathbf{b}}$ : values significantly different microorganisms. These results confirm a statement that the intermediate polarity compounds usually have the highest antimicrobial activity found with many different plant species [31]. The interesting antimicrobial activity of dichloromethane extract against the tested microorganisms could be due to the presence of flavonoids, naphtoquinone and triterpene as reported previously [32-34]. Flavonoids are hydroxylated phenolic substances known to be synthesized by plants in response to microbial infection and they have been found to be antimicrobial substances against wide array of microorganisms in vitro [35]. Flavonoids are known antimicrobial agents throught various mechanisms like inhibition of nucleic acid synthesis, inhibition of cytoplasmic membrane function and energy metabolism [36]. Naphthoquinone and triterpenes have been also reported to possess antibacterial activity [37, 38]. In our study, coumarin and tannin were detected in methanol and aqueous extracts. Coumarins represent a large group of compounds that have been reported to possess a wide range of biological activities including antimicrobial [39] and antioxidant [40]. Tannins are known antimicrobial agents that could inhibit the growth of microorganisms by precipitating the microbial protein and thus depriving them of nutritional proteins needed for their growth and development [41]. This could explain the antimicrobial activity of methanol and aqueous extracts.

DPPH is a stable free radical which accepts an electron or hydrogen radical to become a stable diamagnetic molecule. In the presence of hydrogen doner, DPPH is reduced. It has been showed that the scavenging effects on the DPPH radical increased with the increasing concentration of the samples to a certain extent. In the present study, methanol and aqueous extracts showed appreciable free radical scavenging activity than dichloromethane extract at 500 and $1000 \mu \mathrm{g} / \mathrm{ml}$. This may be due to the different polarities of antioxidant compounds present in the extracts [42]. The difference in the DPPH radical scavenging activity implies that the extracting solvent would affect the presence of secondary metabolites of extract and then the radical scavenging potency. The antioxidant capacity of methanol and aqueous extracts could be due to the presence of phenolic compounds such as coumarins and tannins. Several researches reported the antioxidant activity of these chemical compounds [43-45].

The oral acute toxicity of aqueous extract at $2000 \mathrm{mg} / \mathrm{kg}$ body weight resulted in no mortality and no signs of acute toxicity throughout the 14 days. This suggests that the LD50 is greater than $2000 \mathrm{mg} / \mathrm{kg}$ body weight. The increase in body weight observed between day 1 and 14 in the treated groups could be attributed to the increase in food consumption. This could be explained by an excitation of appetite of animal by aqueous extract. In this case, aqueous extract could have hypoglycemia effect. A 
significant increase $(P<0.05)$ observed in the relative kidney weight of treated animals compare to control could also correlate with the growth of animals or to a dysfunction of kidney cells. Previous studies have shown that a reduction in body weight gain and organ weights is an internal simple and sensitive index of toxicity after-exposure to toxic substances $[46,47]$. Contrary to this, the results of our studies showed an increase in body weight and organs of treated rats. Then, it could be concluded that a change in body weight and organs is an index of toxicity.

Hematological assessment is useful to determine the extent of toxic effects of plant extracts on the blood constituents of an animal [48]. In this study, we found a significant difference in hematological parameters such as $\mathrm{Rbc}, \mathrm{Ht}, \mathrm{MCH}, \mathrm{MCV}, \mathrm{WBC}, \mathrm{Nc}, \mathrm{L}$ and $\mathrm{M}$. Increase in the production of WBC and it's differentials is generally considered to be a marker of stress and a defense mechanism triggered by immune system against various inflammatory conditions (Polymyalgia rheumatica, bacterial infections, hemorrhage, leukemia etc.) [49]. The significant changes in the level of WBC suggest the toxic effect of the leaves of $A$. uliginosa. Creatinin is known as an effective indicator of kidney function and any significant increase in creatinin levels induces functional nephron damage [50]. The significant rise of creatinine concentration in plasma indicates the implicit effect of the plant on renal filtration mechanism. It was noted a significant reduction of AST and ALT in animals treated compared to the control. This could mean that the aqueous extract of A. uliginosa had a harmful effect on the liver. Histological analysis showed lesions in the liver and kidneys. The cellular architecture of these organs confirms the significant changes in hematological and biochemical parameters of treated animals. Coumarins found in A. uliginosa extracts are known for their hepatotoxicity and have been reported to be toxic to rats and mice [51]. Thus, this class of compounds may be involved in the changes caused by the aqueous extract of $A$. uliginosa. The lesions observed in the organs could be due to the presence of pesticide residues and/or heavy metal in the leaves of A. uliginosa, since the gardener use pesticides and the harvest was made in the garden near Cotonou International Airport. Previous study showed that presence of pesticides in leaf-vegetable could justify the increased kidney weight and increased incidence of chronic nephrosis [52].

\section{Conclusion}

Green leafy vegetables contain various pharmacologically active compounds. The presence of active chemical groups such as flavonoids, coumarin, triterpene, naphtoquinone and tannin in the leaves of Acmella uliginosa could justify results obtained. The results of this study confirmed the traditional use of Acmella uliginosa as an antibiotic. Leaves extracts of $A$. uliginosa showed mainly moderate to good activity against the microbial pathogens evaluated. Aqueous extract has showed low oral toxicity on rats since no animal death was detected at a dose of $2000 \mathrm{mg} / \mathrm{kg}$. However, the extract promoted significant modifications of biochemical, hematological parameters and histopathological analysis showed alterations. These results indicate that caution is required regarding its consumption. Acmella uliginosa seems to be of particular interest for future investigations due to the toxicity of the aqueous extract but also because it is consumed by the population. Harvesting must be done in other geographical areas of Benin to reassess the toxicity.

\section{Competing interests}

The authors declare that they have no competing interests.

\section{Authors' contributions}

$\mathrm{LL}$ designed the study, followed the implementation, wrote the manuscript, AMA Collected plant, prepared the extracts and carried out the study, participated to write the manuscript, RA carried out antibacterial and phytochemical test, AL carried out toxicity and histological test, AS coordination and helped to revise the manuscript. All authors read and approved the final manuscript.

\section{Acknowledgements}

The authors are grateful to International foundation for Science (IFS) for laboratory equipment (IFS N F/5673-1). The authors also wish to thank the University of Abomey- Calavi for financial support of their project (PFCR/UAC, $2^{\text {nd }}$ phase).

\section{Author details}

'Unité de Biochimie et Biologie Moléculaire, Equipe de Biochimie et Substances Naturelles Bioactives, Faculté des Sciences et Techniques, Université d'Abomey-Calavi, Cotonou 04 BP 0320, Bénin. ²Unité de Biologie Humaine, Laboratoire de Cytogénétique et de Biologie Moléculaire, Faculté des Sciences de Santé, Université d'Abomey-Calavi, Cotonou, Bénin.

Received: 22 September 2015 Accepted: 22 January 2016 Published: 27 January 2016

\section{References}

1. Maundu PM, Kabuye CHS, Chweya JA. Proceedings of the indigenous food plants workshop. Nairobi: National museums of Kenya; 1993.

2. Fasuyi AO. Nutritional potentials of some tropical vegetable meals, chemical characterization and functional properties. Afr J Biotechnol. 2006;5:49-53.

3. Sharma HP, Kumar RA. Health security in ethnic communities through nutraceutical leafy vegetables. J Environ Res Develop. 2013;7:1423-9.

4. Yadav RK, Kalia P, Kumar R, Jain V. Antioxidant and nutritional activity studies of green leafy vegetables. Int J Agric Food Sci Tech. 2013;4:707-12.

5. Rich-Evan CA, Sampson J, Bramely PM, Hollwa DE. Why we do except carotenoids to be antioxidants in vivo. Free Rad Res. 1997;26:381-98.

6. Jeyadevi R, Sivasudha T, Ilavarasi A, Thajuddin N. Chemical constituents and antimicrobial activity of indian green leafy vegetable Cardiospermum halicacabum. Indian J Microbiol. 2013;53:208-13.

7. Bhojane P, Damle S, Thite A, Dabholkar V. Anti-microbial effects of some leafy vegetables - A comparative analysis. Int Res J Biological Sci. 2014;3:26-32.

8. Oboh G, Akinyemi AJ, Ademiluyi AO, Bello FO. Inhibition of a-amylase and a-glucosidase activities by ethanolic extract of Amaranthus cruentus leaf as affected by blanching. Afr J Pharm Pharmacol. 2013;7:1026-32.

9. Yamamura S, Ozawa K, Ohtani K, Kasai R, Yamasaki K. Antihistaminic flavones and aliphatic glycosides from Mentha spicata. Phytochem. 1998;48:131-6.

10. Khanna AK, Rizvi F, Chander R. Lipid lowering activity of Phyllanthus niruri in hyperlipemic rats. J Ethnopharmacol. 2002;82:19-22.

11. Rajeshkumar NV, Joy KL, Kuttan G, Ramsewak RS, Nair MG, Kuttan R. Antitumour and anticarcinogenic activity of Phyllanthus amarus extract. J Ethnopharmacol. 2002;81:17-22.

12. Pandey V, Agrawal V, Raghavendra K, Dash AP. Strong larvicidal activity of three species of Spilanthes (Akarkara) against malaria (Anopheles 
stephensi Liston, Anopheles culicifacies, species C) and filaria vector (Culex quinquefasciatus Say). Parasitol Res. 2007;102:171-4.

13. Dansi A, Adjatin A, Adoukonou-Sagbadja H, Faladé V, Yedomonhan H, Odou $D$, et al. Traditional leafy vegetables and their use in the Benin Republic. Genet Resour Crop Evol. 2008;55:1239-56.

14. Etèka CA, Ahohuendo BC, Ahoton LE, Dabadé SD, Ahanchédé A. Seeds' germination of four traditional leafy vegetables in Benin (LFT). Tropicultura. 2010;28:148-52.

15. Ong HM, Mohamad AS, Makhtar N, Khalid MH, Khalid S, Perimal EK, et al. Antinociceptive activity of methanolic extract of Acmella uliginosa (Sw.) Cass. J Ethnopharmacol. 2011;133:227-33.

16. Wagner H, Bladt S. Plant drug analysis. 2nd ed. Berlin, Germany: SpringerVerlag; 2001.

17. Bruneton J. Pharmacognosie, phytochimie, plantes médicinales. 4th ed. TEC et DOC; Paris; 2009. p 456

18. Eloff JN. A sensitive and quick method to determine the minimal inhibitory concentration of plant extracts for bacteria. Planta Med. 1998;64:711-3.

19. Keymanesh K, Hamedi J, Moradi S, Mohammadipanah F, Sardari S. Antibacterial, antifongique and toxicity of rare Iranian plants. Int J Pharm. 2009;5:81-5.

20. Eloff JN, Katerere DR, McGaw LJ. The biological activity and chemistry of the southern African combretaceae. J Ethnopharmacol. 2008;119:686-99.

21. Eloff JN. Quantification the bioactivity of plant extracts during screening and bioassay guided fractionation. Phytomedicine. 2004;11:370-1.

22. Sasidharan S, Prema B, Yoga LL. Antimicrobial drug resistance of Staphylococcus aureus in dairy products. Asian Pac J Trop Biomed. 2011;1:130-2.

23. Dohou N, Yamni K, Badoc A. Activité antifongique d'extraits de Thymelaea lythroides sur trois champignons pathogènes du riz. Bull Soc Pharm Bord. 2004;143:31-38

24. Velazquez E, Tournier HA, Buschiazzo MP, Saavedra G, Schinella GR. Antioxydant activity of Paraguayan plant extracts. Fitoterapia. 2003;74:91-7.

25. Organization for Economic Cooperation and Development. "Guidelines for the testing of chemicals/section 4: Health effects test no. 423: Acute oral toxicity - Acute toxic class method," Paris, France; 2002.

26. Kuete V. Potential of Cameroonian plants and derived products against microbial infections: a review. Planta Med. 2010;76:1479-91.

27. Olson H, Betton G, Robinson D, Thomas K, Monro A, Kolaja G, et al. Concordance of the toxicity of pharmaceuticals in humans and in animals. Regul Toxicol Pharmacol. 2000;32:56-67.

28. Dong $M, H e X$, Rui HL. Phytochemicals of black bean seed coats: isolation, structure elucidation, and their antiproliferative and antioxidative activities. J Agric Food Chem. 2007:55:6044-51.

29. Bhat RS, Al-Daihan S. Phytochemical constituents and antibacterial activity of some green leafy vegetables. Asian Pac J Trop Biomed. 2014:4:189-93.

30. Jain AK, Tiwari P. Nutritional value of some traditional edible plants used by tribal communities during emergency with reference to Central India. Indian J Trad Knowl. 2012;11:51-7.

31. Eloff JN, McGaw $\sqcup$. Using African plant biodiversity to combat microbial infections. In Novel Plant Bioresources: Applications in food medicine and cosmetics. Edited by Gurib-Fakim A. Ltd: John Wiley and Sons; 2014. 163-173. doi: 10.1002/9781118460566.ch12.

32. Özçelik B, Orhan DD, Özgen S, Ergun F. Antimicrobial activity of flavonoids against extended-spectrum $\beta$-lactamase (ES $\beta \mathrm{L}$ )-producing Klebsiella pneumoniae. Trop J Pharm Res. 2008;7:1151-7.

33. Chen WH, Liu WJ, Wang Y, Song XP, Chen GY. A new naphthoquinone and other antibacterial constituents from the roots of Xanthium sibiricum. Nat Prod Res. 2015:29:739-44

34. Ferreira Mdo P, Cardoso MF, da Silva FC, Ferreira VF, Lima ES, Souza JV. Antifungal activity of synthetic naphthoquinones against dermatophytes and opportunistic fungi: preliminary mechanism-of-action tests. Ann Clin Microbiol Antimicrob. 2014:13:26.

35. Mandal S, Patra A, Samanta A, Roy S, Mandal A, Das Mahapatra T, et al. Analysis of phytochemical profile of Terminalia arjuna bark extract with antioxidative and antimicrobial properties. Asian Pac J Trop Biomed. 2013;3:960-6.

36. Cushnie TP, Lamb AJ. Antimicrobial activity of flavonoids. Int J Antimicrob Ag. 2005;26:343-56.

37. Tandon VK, Yadav DB, Singh RV, Vaish M, Chaturvedi AK, Shukla PK. Synthesis and biological evaluation of novel 1,4-naphtoquinones derivatives as antibacterial and antiviral agents. Bioorg Med Chem Lett. 2005;15:3463-6.
38. Mann A, Ibrahim K, Oyewale AO, Amupitan JO, Fatope MO, Okogun Jl. Isolation and elucidation of three triterpenoids and its antimycobacterial activty of Terminalia Avicennioides. Am J Org Chem. 2012;2:14-20.

39. Nitiema LW, Savadogo A, Simpore J, Dianou D, Traore AS. In vitro antimicrobial activity of some phenolic compounds (coumarin and quercetin) against gastroenteritis bacterial strains. Int J Microbiol Res. 2012;3:183-7.

40. Basile A, Sorbo S, Spadaro V, Bruno M, Maggio A, Faraone N, et al. Antimicrobial and antioxidant activities of coumarins from the roots of Ferulago campestris (Apiaceae). Molecules. 2009;14:939-52.

41. Obasi Nnamdi L, Egbuonu ACC, Ukoha PO, Ejikeme PM. Comparative phytochemical and antimicrobial screening of some solvent extracts of Samanea saman (fabaceae or mimosaceae) pods. Afr J Pure Appl Chem. 2010:4:206-12.

42. Goh SH, Yusoff F, Loh SP. A comparison of the antioxidant properties and total phenolic content in a Diatom, Chaetoceros sp. and a Green Microalga, Nannochloropsis sp. J Agric Sci. 2010;2:123-30.

43. Pereira DM, Valentão P, Pereira JA, Andrade PB. Phenolics: from chemistry to biology. Molecules. 2009;14:2202-11.

44. Zhang SJ, Lin YM, Zhou HC, Wei SD, Lin GH, Ye GF. Antioxidant tannins from stem bark and fine root of Casuarina equisetifolia. Molecules. 2010;15: 5658-70.

45. Kadhum AAH, Al-Amiery AA, Musa AY, Mohamad AB. The antioxidant activity of new coumarin derivatives. Int J Mol Sci. 2011;12:5747-61.

46. Raza M, Al-Shabanath OA, El-Hadiyah TM, Al-Majed AA. Effect of prolonged vigabatrin treatment on hematological and biochemical parameters in plasma, liver and kidney of Swiss albino mice. Sci Pharm. 2002;70:135-45.

47. Teo S, Strlig D, Thomas S, Hoberman A, Kiorpes A, Khetani V. A 90-days oral gavage toxicity study of D-methylphenidate and $\mathrm{D}, \mathrm{L}$-methylphenidate in sprague-dawley rats. Toxicology. 2002;79:183-96.

48. Ashafa AOT, Yakubu MT, Grierson DS, Afolayan AJ. Effects of aqueous leaf extract from the leaves of Chrysocoma ciliate L. on some biochemical parameters of Wistar rats. Afr J Biotechnol. 2009;8:1425-30.

49. Uddin N, Hasan R, Hasan M, Hossain M, Alam R, Hasan MR, et al. Assessment of toxic effects of the methanol extract of Citrus macroptera Montr. Fruit via biochemical and hematological evaluation in female sprague-dawley rats. PLoS One. 2014;9, e111101. doi:10.1371/journal.pone.0111101.

50. Pillaia PG, Suresha P. Gitanjali M, Annapurna M. Evaluation of the acute and sub-acute toxicity of the methanolic leaf extract of Plectranthus amboinicus (Lour) spreng in balb C mice. Eur J Exp Biol. 2011;1:236-45.

51. Akah PA, Osigwe CC, Nworu CS. Reversal of coumarin-induced toxicity by the extracts and fractions of Ageratum conyzoides. Asian J Med Sci. 2010:2:121-6.

52. FAO. Pesticide Residues in Food 1992 - Report, FAO Plant Production and Protection. Rome: FAO; 1992. p. 63. Paper No. 116

\section{Submit your next manuscript to BioMed Central and we will help you at every step:}

- We accept pre-submission inquiries

- Our selector tool helps you to find the most relevant journal

- We provide round the clock customer support

- Convenient online submission

- Thorough peer review

- Inclusion in PubMed and all major indexing services

- Maximum visibility for your research

Submit your manuscript at www.biomedcentral.com/submit 